UDK 613.294: 614.31: 579.67 (470.43)

\title{
POPULATION HEALTH RISK ASSESSMENT FROM CONTAMINATION OF FOOD PRODUCTS WITH CONTAMINANTS (C.D. SAMARA, C.D. TOGLIATTI)
}

\section{N.M. Tsunina, L.V. Ayupova}

Samara Region Department of the Federal Service on Consumer Rights Protection and Human Well-Being Surveillance , 1, Mitireva St., Samara, 443079, Russia

\begin{abstract}
The introduction in socio-hygienic monitoring of methodologies for risk assessment of negative impact on human health of food contamination with chemical substances was carried according to the methodical documents intended for practical use in Rospotrebnadzor, allowing to select a system of formulas, necessary for research, built in sequence: the dynamics of the amount of the studies presented to the federal information fund of public health monitoring for the long period of time, the sampling of products and food contaminants, depending on the amount of information data, the calculation of the median and the 90th percentile, the exposure of contaminants in foods, the percentage distribution of the contribution of food groups in exposure, the risk of non-carcinogenic and carcinogenic effects.
\end{abstract}

Key words: socio-hygienic monitoring, contamination of food, health risk assessment.

The socio-hygienic monitoring (SHM) conducted by Rospotrebnadzor in Samara Region (hereinafter - Agency) includes a study of food product and food stock safety, analysis of the regulated indicators based on laboratory studies. SHM for the purposes of hygienic diagnostics includes a public health risk assessment program. Chemical exposure was assessed (quantitative assessment of the level of contact with the chemical reagent over a period of time) following the guidelines of the section "Contamination of food products by chemical substances"; calculations and assessment of potential carcinogenic and non-carcinogenic risks - health hazard likelihood $[2,3,5]$. Foreign substances may have a negative impact on organs and trigger a disease. Hazardous substances often may accumulate in a human body resulting from chronic administration with food products.

The analyzed contaminants are for chemicals which get into food products because of incorrect cultivation of vegetables and fruit, storage, transportation and other reasons. Of the total amount of studies in 2006-2013 in each of the areas, most laboratory studies took place in Samara: in $2007-29 \%$ and in $2011-21 \%$; in Toliatti - in $2007-29 \%$ and in $2008-20 \%$ (Table 1).

(C) Tsunina N.M., Ayupova L.V., 2014

Tsunina Natalia Mikhailovna - Deputy Head of Department of Social and Health Monitoring (e-mail: sancntr@fsnsamara.ru; tel.: 8 (846) 260-38-23).

Aiupova Luiza Venerovna - specialist of the 1st class of Department of Social and Health Monitoring, clinical physician (e-mail: sancntr@fsnsamara.ru; tel.: 8 (846) 260-38-23). 
In 2013, we analyzed the data from 9925 studies of food product chemical contamination in Samara conducted in 2010-2012. The ratio of the null values in the sample for each of the three years did not exceed $60 \%$ and totaled, on average, $6,1 \%$.

Table 1

\section{The number of studies on chemical contamination of food products in 2006-2013 presented to the FIF $^{1}$}

\begin{tabular}{|l|c|c|c|c|c|c|c|c|}
\hline \multicolumn{1}{|c|}{ Area } & 2006 & 2007 & 2008 & 2009 & 2010 & 2011 & 2012 & 2013 \\
\hline Samara region & 3535 & 15714 & 8203 & 5970 & 5861 & 9398 & 7034 & 6409 \\
\hline Samara & 1555 & 8814 & 3198 & 1497 & 2693 & 6446 & 3662 & 2734 \\
\hline Toliatti & 233 & 2764 & 1857 & 1118 & 866 & 869 & 687 & 1042 \\
\hline
\end{tabular}

\section{General information for 2010-2012 about chemical contaminants in food products (based on $R$ 2.1.10.1920-04)}

\begin{tabular}{|l|l|c|c|c|c|}
\hline \multirow{2}{*}{ CAS } & \multicolumn{1}{|c|}{ Substance } & $\begin{array}{c}\text { RfD, } \mathrm{mg} / \mathrm{kg} \\
\text { (reference dose, } \\
\text { concentration)* }\end{array}$ & $\begin{array}{c}\text { SFO** } \\
\text { (sloping factor) }\end{array}$ & $\begin{array}{c}\text { Cancer effect } \\
\text { group }\end{array}$ & $\begin{array}{c}\text { Cancer effect } \\
\text { group }\end{array}$ \\
\hline $50-32-8$ & Benzo(a)pyrene* & 0,0005 & 7,3 & $2 \mathrm{~A}$ & B2 \\
\hline $1336-36-3$ & $\begin{array}{l}\text { Polychlorinated } \\
\text { biphenyls }\end{array}$ & None & 0,4 & $2 \mathrm{~A}$ & B2 \\
\hline $118-74-1$ & Hexachlorbenzene & 0,00017 & 1,6 & $2 \mathrm{~B}$ & B2 \\
\hline $7440-02-0$ & Nickel & 0,02 & None & $2 \mathrm{~B}$ & A \\
\hline $7440-47-3$ & Chrome & 0,005 & None & 3 & A \\
\hline $50-29-3$ & DDT & 0,0005 & 0,34 & $2 \mathrm{~B}$ & B2 \\
\hline $7440-38-2$ & Arsenic & 0,0003 & 1,5 & 1 & A \\
\hline $7440-43-9$ & Cadmium & 0,0005 & 0,38 & 1 & B1 \\
\hline $7439-92-1$ & Lead & 0,0035 & 0,047 & $2 \mathrm{~A}$ & B2 \\
\hline $7439-97-6$ & Mercury & 0,0003 & None & None & None \\
\hline $14797-55-8$ & Nitrates & 1,6 & None & None & None \\
\hline
\end{tabular}

$\mathrm{N}$ o t e: carcinogens are highlighted in grey.

* - reference level of exposure (dose or concentration) to the chemical substance that is not harmful even in the event of life-long contact (determined based on the maximum dose that has no effect and the minimum dose that has the biological effect under study)

** - sloping factor shows carcinogenic potential which reflects the increase in cancer risk under exposure to the effect dose)

*** - carcinogen classification (IARC): 1 - known human carcinogens; $2 \mathrm{~A}$ - probable carcinogens; $2 \mathrm{~b}$ - possible carcinogens; 3 - agents that are not classified by cancer activity; 4 - agents that probably bear no cancer hazard for humans.

The following food products appeared to be on the priority list based on the average number of studies (availability of information): milk and milk products, vegetable oil and other faits, meat and meat products (100-75\%) followed by (in the descending order) sugar and confectionery, fish and fish products, vegetables and the gourds, bread and bread products, potatoes, fruits and berries The actual volume of available data did not contradict the recommended volumes (recommended number of samples).

\footnotetext{
${ }^{1}$ Federal Information Foundation
} 
${ }^{2}$ Regional Information Foundation

Table 2 shows general information about chemical contaminants in food products. In the course of a preliminary analysis, we excluded such contaminants as aflatoxin, penicidin, benzo(a)pyrene, T-2-toxin, desoxynivalenol, hexachlorobenzene, zearalenone, 2,4-D-amine salt, 2,4-D-butyl ether, 2,4-D-crotile ether - because the data was collected only over the period of one year (2010) out of the three years of the study. In 2012-2011, the contaminants were not studied or were inconsistent; moreover, they were not included in the list of priority products.

Table [4] includes the groups of products, food product consumption in kilograms per year per person, recommended and actual total and per annum (out of the three years) amount of samples, studies, their average number per period under study and the ranking in accordance with the Guidelines for the Rational Standards of Food Product Consumption that Meets Today's Health Requirements (approved by the RF Department of Public Health and Social Development, Decree №593n of August 2, 2010)

The actual amount of available data did not contradict the recommended volumes (recommended number of samples). In 2012, as compared to 2010-2011, the average concentrations increased: in bread and bread products - of lead, mercury, and DDIT; in vegetables and the gourds - of mercury and arsenic; in meat and meat products - of lead, mercury, and DDT; in milk and dairy products - of arsenic; in fish and fish products - of mercury; in vegetable oil and other fats - of lead and DDT (Table 3).

The calculations of the excess frequency as compared to the maximum permissible concentrations of the average level of priority chemical contaminants in the main food products in Samara for the period of 2010-2012 showed that lead was indentified in 100\% of laboratory tests, there was no excess compared to MPC; cadmium was identified in $85 \%$ of laboratory test, and it exceeded MPC by 1.028 times in vegetables and the gourds; arsenic - in $100 \%$ of laboratory tests, no excess as compared to MPC; DDT - in $98 \%$ of laboratory tests, exceeded MPC by 1.13 times, was identified in bread and bread products.

To evaluate the level of exposure, we used the median of contaminant concentration in food products and the 90th percentile (2010-2012) as shown in Table 4. Additionally, we provided the results of the evaluation of exposure to food product contaminants (Table 5). Exposure evaluions and the calculation of the contribution of each of the product groups in the total exposure value was conducted based on the following formulas (1) and (2). 
Table 3

Increase $(+)$ in the chemical concentrations in the main food product groups in Samara in 2012 as compared to 2010-2011

\begin{tabular}{|l|c|c|c|c|c|}
\hline \multicolumn{1}{|c|}{ Product group } & Lead & Mercury & Cadmium & Arsenic & DDT \\
\hline Bread and bread products & + & + & - & - & + \\
\hline Potatoes & - & - & - & - & - \\
\hline Vegetables and the gourds & - & + & - & + & - \\
\hline Fruits and berries & - & - & - & - & - \\
\hline Meat and meat products & + & + & - & - & + \\
\hline Milk and dairy products & - & - & - & + & - \\
\hline Fish and fish products & - & + & - & - & \\
\hline Sugar and confectionaries & - & + & - & - & + \\
\hline Vegetable oil and other fats & + & - & - & - & + \\
\hline
\end{tabular}

Table 4

Toxic concentrations in the main food products consumed in Samara (2010-2012), $\mathrm{mg} / \mathrm{kg}$

\begin{tabular}{|l|c|c|c|c|c|c|c|c|c|c|}
\hline \multicolumn{1}{|c|}{ Product group } & \multicolumn{2}{|c|}{ Lead } & \multicolumn{2}{c|}{ Mercury } & \multicolumn{2}{c|}{ Cadmium } & \multicolumn{2}{c|}{ Arsenic } & \multicolumn{3}{c|}{ DDT } \\
\cline { 2 - 12 } & Median & $\begin{array}{c}90 \text { th } \\
\text { percentile }\end{array}$ & Median & $\begin{array}{c}90 \text { th } \\
\text { percentil } \\
\text { e }\end{array}$ & Median & $\begin{array}{c}90 \text { th } \\
\text { percentil } \\
\text { e }\end{array}$ & Median & $\begin{array}{c}90 \text { th } \\
\text { percentile }\end{array}$ & $\begin{array}{c}\text { Median } \\
\text { percentil } \\
\text { e }\end{array}$ \\
\hline $\begin{array}{l}\text { Bread and bread } \\
\text { products }\end{array}$ & 0,1 & 0,1 & 0,0034 & 0,005 & 0,02 & 0,02 & 0,008 & 0,008 & 0,0113 & 0,012 \\
\hline Potatoes & 0,0334 & 0,045 & 0,0072 & 0,01 & 0,0118 & 0,0145 & 0,025 & 0,025 & 0,0061 & 0,0075 \\
\hline $\begin{array}{l}\text { Vegetables and the } \\
\text { gourds }\end{array}$ & 0,0511 & 0,061 & 0,0039 & 0,0062 & 0,0305 & 0,0407 & 0,0175 & 0,0194 & 0,0053 & 0,0065 \\
\hline Fruits and berries & 0,0087 & 0,0087 & 0,0021 & 0,004 & 0,01 & 0,01 & 0,025 & 0,025 & 0,005 & 0,005 \\
\hline $\begin{array}{l}\text { Meat and meat } \\
\text { products }\end{array}$ & 0,0841 & 0,1817 & 0,0464 & 0,0088 & 0,1222 & 0,025 & 0,2616 & 0,0253 & 0,0311 & 0,0123 \\
\hline $\begin{array}{l}\text { Milk and dairy } \\
\text { products }\end{array}$ & 0,08 & 0,08 & 0,0166 & 0,0126 & 0,0138 & 0,0239 & 0,0182 & 0,0313 & 0,005 & 0,005 \\
\hline $\begin{array}{l}\text { Fish and fish } \\
\text { products }\end{array}$ & 0,1254 & 0,17 & 0,02 & 0,0227 & 0,01 & 0,01 & 0,0244 & 0,0256 & 0,005 & 0,0055 \\
\hline $\begin{array}{l}\text { Sugar and } \\
\text { confectionaries }\end{array}$ & 0,0393 & 0,0835 & 0,0036 & 0,0057 & 0,0075 & 0,01 & 0,0225 & 0,025 & 0,0042 & 0,0052 \\
\hline $\begin{array}{l}\text { Vegetable oil and } \\
\text { other fats }\end{array}$ & 0,0291 & 0,0633 & 0,0037 & 0,0043 & 0,01 & 0,01 & 0,0173 & 0,0244 & 0,005 & 0,005 \\
\hline
\end{tabular}

Table 5

Evaluation of exposure to food product contaminants, $\mathrm{mg} / \mathrm{kg}$ body mass/week

\begin{tabular}{|l|c|c|}
\hline \multirow{2}{*}{ Substance } & \multicolumn{2}{|c|}{ Exposure evaluate based on } \\
\cline { 2 - 3 } & medians & 90th percentile \\
\hline Lead & 0,01368 & 0,01697 \\
\hline Mercury & 0,00088 & 0,00194 \\
\hline Cadmium & 0,00376 & 0,00669 \\
\hline Arsenic & 0,00376 & 0,00669 \\
\hline DDT & 0,00098 & 0,00123 \\
\hline
\end{tabular}

Public exposure to food contaminants is calculated based on the formula:

$$
E_{\mathrm{xp}}=\frac{\operatorname{SUM}_{i=1}^{N}\left(C_{I} \cdot M_{i}\right)}{B W},
$$


where Exp - value of exposure to contaminants, $\mathrm{mg} / \mathrm{kg}$ body weight $/ \mathrm{day}(\mathrm{mg} / \mathrm{kg}$ body weight /week, mg/kg body weight); $\mathrm{C}$ - contaminant concentration in the i product, $\mathrm{mg} / \mathrm{kg}$; ${ }^{M_{i}^{i}}-$ consumption of the i product, $\mathrm{kg}$ /day ( $\mathrm{kg} /$ week, $\mathrm{kg} /$ year); $\mathrm{BW}$ - human body weight, $\mathrm{kg}$ (standard value $-70 \mathrm{~kg}$ ); $\mathrm{N}$ - total amount of products included in the study.

Contribution of individual products to the total exposure to food contaminants is based on the formula:

$$
C_{\text {ontr }}=\frac{C_{I} \cdot M_{i}}{\operatorname{SUM}_{i=1}^{N}\left(C_{I} \cdot M_{i}\right)},
$$

where Contr - contribution of the i product to the total exposure value; $C_{I}-$ contaminant concentration in the i product, mg/kg; $M_{i}$ - consumption of the i product, $\mathrm{kg} /$ day $(\mathrm{kg} / \mathrm{week}$, $\mathrm{kg} /$ year). Then we calculated the percent contribution of a product group to the total exposure (Table 6) and the group rankings based on individual contributions in the descending order of contribution.

Table 6

Contribution of food products to the total chemical exposure and individual administration

\begin{tabular}{|l|c|c|c|c|c|c|c|c|c|c|}
\hline & \multicolumn{2}{|c|}{ Lead } & \multicolumn{2}{c|}{ Mercury } & \multicolumn{2}{c|}{ Cadmium } & \multicolumn{2}{c|}{ Arsenic } & \multicolumn{2}{c|}{ DDT } \\
\cline { 2 - 13 } & $\begin{array}{c}\text { Product group } \\
\text { ontribu } \\
\text { on, } \\
\%\end{array}$ & $\begin{array}{c}\text { administrati } \\
\text { on, } \mathrm{mg} / \mathrm{kg}\end{array}$ & $\begin{array}{c}\text { ontribu } \\
\text { on, } \\
\%\end{array}$ & $\begin{array}{c}\text { administrati } \\
\text { on, } \mathrm{mg} / \mathrm{kg}\end{array}$ & $\begin{array}{c}\text { ontribu } \\
\text { on, } \\
\%\end{array}$ & $\begin{array}{c}\text { administrati } \\
\text { on, } \mathrm{mg} / \mathrm{kg}\end{array}$ & $\begin{array}{c}\text { ontribu } \\
\text { on, } \\
\%\end{array}$ & $\begin{array}{c}\text { administrati } \\
\text { on, } \mathrm{mg} / \mathrm{kg}\end{array}$ & $\begin{array}{c}\text { ontribu } \\
\text { on, } \\
\%\end{array}$ & $\begin{array}{c}\text { administrati } \\
\text { on, } \mathrm{mg} / \mathrm{kg}\end{array}$ \\
\hline $\begin{array}{l}\text { Bread and } \\
\text { bread products }\end{array}$ & 22 & 10,6300 & 11 & 0,3585 & 18 & 2,1260 & 6 & 0,8504 & 19 & 1,2031 \\
\hline Potatoes & 4 & 2,2000 & 15 & 0,4745 & 6 & 0,7798 & 12 & 1,6475 & 7 & 0,4044 \\
\hline $\begin{array}{l}\text { Vegetables and } \\
\text { the gourds }\end{array}$ & 10 & 4,8400 & 12 & 0,3705 & 25 & 2,8882 & 12 & 1,6568 & 8 & 0,5016 \\
\hline $\begin{array}{l}\text { Fruits and } \\
\text { berries }\end{array}$ & 1 & 0,5800 & 5 & 0,1411 & 6 & 0,6720 & 13 & 1,6800 & 5 & 0,3360 \\
\hline $\begin{array}{l}\text { Meat and meat } \\
\text { products }\end{array}$ & 13 & 6,2900 & 16 & 3,4690 & 10 & 1,1295 & 12 & 1,5772 & 36 & 2,2440 \\
\hline $\begin{array}{l}\text { Milk and dairy } \\
\text { products }\end{array}$ & 41 & 20,1600 & 23 & 3,6514 & 30 & 3,4691 & 34 & 4,5781 & 20 & 1,2600 \\
\hline $\begin{array}{l}\text { Fish and fish } \\
\text { products }\end{array}$ & 5 & 2,5300 & 13 & 0,4048 & 2 & 0,2070 & 4 & 0,4924 & 2 & 0,1006 \\
\hline $\begin{array}{l}\text { Sugar and } \\
\text { confectionaries }\end{array}$ & 3 & 1,3100 & 4 & 0,1192 & 2 & 0,2505 & 6 & 0,7515 & 2 & 0,1388 \\
\hline $\begin{array}{l}\text { Vegetable oil } \\
\text { and other fats }\end{array}$ & 1 & 0,3100 & 1 & 0,0393 & 1 & 0,1070 & 1 & 0,1856 & 1 & 0,0535 \\
\hline
\end{tabular}

According to the reduced calculations, the biggest contributors to the chemical exposure of all the product groups are milk and dairy products, vegetables and the gourds, meat and meat products. Calculations of the hazard quotients for the food products the reflect the ratio of the measured dose of contaminants to the permissible (risk of noncancer effects) showed that in terms of concentrations: lead HQ med 
and HQ $90 \%=0,6789$; mercury concentration HQ med =0,6007 and HQ $90 \%=0,0614$; $\begin{array}{llll}\text { cadmium } & \text { concentration } & = & 0,4653\end{array}$ and HQ 90\% = 0,6467; arsenic concentration HQ med =0,2506 and HQ 90\% =0,4457; $\begin{array}{lllll}\text { DDT } & \text { concentration } & \text { HQ med } & 1,9733\end{array}$ and HQ $90 \%=2,4619$.

By the median values and the 90th percentile, the levels of lead, mercury, cadmium, arsenic did not exceed one; also, exposure was permissible; DDT had a higher value than one which means DDT required additional advanced exposure evaluation. Based on the analysis of DDT concentration in food products, it was determined that the biggest contributors to the exposure associated with this contaminant by the median of its content are bread and confectionaries $-85 \%$; whole milk $-2 \%$; potatoes $-4 \%$; onions, cabbage, carrots, beets, meat, grits, grains, wheat flour, sugar, fruits, and berries $-1 \%$ each; based on the 90 th percentile of DDT concentration, the biggest contributor is tinned fish $-18 \%$ (other products $-4 \%$ each). Arsenic is in the group of chemicals which bear cancer risks regardless the type of administration $^{1}$.

Table 7

Noncancer risk associated with arsenic exposure in food products (population at large)

\begin{tabular}{|l|c|c|}
\hline \multicolumn{1}{|c|}{ Food product groups } & $\begin{array}{c}\text { Calculated average exposure, } \\
\mathrm{mg} / \mathrm{kg} / \text { day }\end{array}$ & Hazard quotient $(H Q)$ \\
\hline Bread and bread products & 0,000022 & 0,001 \\
\hline Potatoes & 0,000068 & 0,004 \\
\hline Vegetables and the gourds & 0,000048 & 0,003 \\
\hline Meat and meat products & 0,000058 & 0,004 \\
\hline Milk and dairy products & 0,000050 & 0,003 \\
\hline Fish and fish products & 0,000067 & 0,004 \\
\hline Sugar and confectionaries & 0,000062 & 0,004 \\
\hline Vegetable oil and other fats & 0,000048 & 0,003 \\
\hline Fruits and berries & 0,000068 & 0,005 \\
\hline
\end{tabular}

Table 8

Cancer risk associated with arsenic exposure in food products (population at large)

\begin{tabular}{|l|c|c|c|}
\hline \multicolumn{1}{|c|}{ Affected organs } & $(\mathrm{mg} / \mathrm{kg} / \text { day) })^{-1}$ & $\begin{array}{c}\text { Individual risk } \\
\text { (probability) }\end{array}$ & $\begin{array}{c}\text { Population risk } \\
\text { (number of cases) }\end{array}$ \\
\hline Liver & 1 & $2,4 \mathrm{E}-04$ & 280 \\
\hline Lungs & 2,5 & $6,0 \mathrm{E}-04$ & 702 \\
\hline Bladder & 2,5 & $6,0 \mathrm{E}-04$ & 702 \\
\hline Kidney & 0,86 & $2,0 \mathrm{E}-04$ & 241 \\
\hline Sking & 1,5 & $3,6 \mathrm{E}-04$ & 421 \\
\hline All cancer sites & - & $20,0 \mathrm{E}-03$ & 2348 \\
\hline
\end{tabular}

Tables 7 and 8 show the results of evaluation of the noncancer and cancer risks associated with peroral arsenic administration. Arsenic, lead and cadmium have cumulative capabilities and

\footnotetext{
${ }^{1}$ Sanitary Regulations and Standards 1.2.2353-08 Carcinogenic Factors and General Reguirements to Cancer Prevention.
} 
are among priority food contaminants. Proportional to the increase in the total contribution of the indicated contaminants to the exposure is higher hazard quotient and the risk to affect human organs and systems [1].

The assessment of cancer risks associated with peroral arsenic exposure indicates that the risk is average and that the possibility of a malignant tumor in prospect. Estimated number of malignant tumors in prospect for the studied population provided that the exposure and population size are constant constitute 20 cases per 10000 population in Samara.

The data on food contamination in Toliatti was processed in 2012 based on the laboratory test for 2006-2011. The study results showed that in Toliatti, milk, buttermilk, lactoserum, liquid fermented milk (1483 tests) contained metals (arsenic, lead, cadmium, mercury - in 97\%) at below the permissible levels which was in accordance with the federal guidelines. Milk is known to be a university and irreplaceable product for children and adults. It contains a balanced mix of necessary microelements. Milk is often provided to employees as part of the medical and preventative activities to prevent professional illnesses. Additionally, milk increases the overall functioning of a human body, alleviates the effects of radioactive and other toxic substances at industrial enterprises

However when implementing a nonorganic effect alleviation program, we recommend that you take lactic acid bacteria products (butter milk, sour milk, bifidok, etc.), pectin, (contained in the citruses, apples, radish, beets, and other fruits and vegetables). These products are irreplaceable for the residents of industrial areas since they further the cleansing of a human body from hazardous substances that come from the outside (lead to decreased absorption of toxic chemicals and fast elimination from the body).

\section{References}

1. Kislitsina L.V., Zhigaev D.S., Anan'ev V.Yu., Kiku P.F. Gigienicheskaya otsenka soderzhaniya kontaminantov $\mathrm{v}$ produktakh pitaniya po dannym sotsial'no-gigienicheskogo monitoringa [Hygienic evaluation of the content of contaminants in food products according to public health monitoring]. Aktual'nye napravleniya razvitiya sotsial'no-gigienicheskogo monitoringa $i$ analiza riska zdorov'yu: materialy Vserossiyskoy nauchno-prakticheskoy konferentsii s mezhdunarodnym uchastiem. Ed. akademik RAMN G.G.Onishchenko, akademik RAMN N.V. Zaytseva. Perm': Knizhnyy format, 2013, pp. 187-194.

2. Opredelenie ekspozitsii i otsenka riska vozdeystviya khimicheskikh kontaminantov pishchevykh produktov na naselenie. Metodicheskie ukazaniya (MU 2.3.7.2519-09) [Determination of exposure and risk assessment of exposure to chemical contaminants in food for the population. Methodical instructions (MU 2.3.7.2519-09)]. Moscow: Fede-ral'nyy tsentr gigieny i epidemiologii Rospotrebnadzora, 2010. 27 p.

3. Sotsial'no-gigienicheskiy monitoring. Kontaminatsiya prodovol'stvennogo syr'ya i pishchevykh produktov khimicheskimi veshchestvami. Sbor, obrabotka i analiz pokazateley 
(MU 2.3.7.2125-06) [Socio-hygienic monitoring. Contamination of food raw materials and food chemicals. Collection, processing and analysis of indicators (MU 2.3.7.2125-06)]. Moscow: Federal'nyy tsentr gigieny i epidemiologii Rospotrebnadzora. $10 \mathrm{p}$.

4. O primenenii sanitarnykh mer v Tamozhennom soyuze. Edinyy perechen' tovarov, podlezhashchikh sanitarno-epidemiologicheskomu nadzoru (kontrolyu) na tamozhennoy granitse i tamozhennoy territorii tamozhennogo soyuza [On the application of sanitary measures in the Customs Union. Single list of goods subject to sanitary and epidemiological supervision (control) at the customs border and the customs territory of the Customs Union]. Evraziyskoe ekonomicheskoe soobshchestvo. Komissiya tamozhennogo soyuza. Reshenie ot 28 maya $2010 \mathrm{~g}$. N 299, pp. 59-342.

5. Rukovodstvo po otsenke riska dlya zdorov'ya naseleniya pri vozdeystvii khimicheskikh veshchestv, zagryaznyayushchikh okruzhayushchuyu sredu (R 2.1.10.1920-04) [Risk assessment guidance for public health from exposure to chemicals polluting the environment (R 2.1.10.1920-04)]. Moscow: Federal'nyy tsentr Gossanepidnadzora Minzdrava Rossii, 2004. 143 p. 